\title{
Görsel Sanatlar Öğretmen Adaylarının ve Öğretmenlerinin Sanatçı ve Öğretmen Kavramlarına Yönelik Tutumları*
}

\author{
Zümrüt Şen **, Raif Kalyoncu***
}

Makale Geliş Tarihi: 28/11/2019

Makale Kabul Tarihi: 03/02/2020

DOI: $10.35675 /$ befdergi. 652210

$\ddot{O} z$

Bu araştırmanın amacl; Görsel Sanatlar öğretmen adaylarının ve öğretmenlerinin sanatçı ve öğretmen kavramlarlyla ilgili bilgi ve tutumlarını incelemektir. Araştırmanın deseni; nicel yaklaşıma dayalı betimsel araştırma yöntemidir. Araştırmanın çalışma grubunu, Karadeniz Teknik Üniversitesi Fatih Eğitim Fakültesi Görsel Sanatlar Eğitimi Bölümü Resim İş Öğretmenliği Ana Bilim Dalı ’nda örgün ve ikinci öğretimde öğrenim gören 176 öğretmen adayl ve Trabzon ili il ve ilçe merkezlerinde Milli Ĕ̈itim Bakanlı̆̆ı'na bağll okullarda görev yapan 100 Görsel Sanatlar Öğretmeni oluşturmaktadır. Araştırmada veri toplamak amacıyla; "Kişisel Bilgi Formu”, araştırmacı tarafindan geliştirilen "Sanatçı ve Öğretmen Kavramlarına Yönelik Tutum Ölçeği” kullanılmıştır. Veri analizi için tanımlayıcı teknikler ile bağımsız t testi ve parametrik olmayan veriler için Kruskall-Wallis teknikleri kullanılmıştır. Sonuçların bir kısmı literatür bulgularıyla benzerlik gösterirken bir kısmı benzerlik göstermemiştir. Bu durum literatür bulgularıyla tartışılmıştır. Sonuç olarak da araştırmaya ve ileride yapılacak olan araştırmalara yönelik önerilerde bulunulmuştur.

Anahtar Kelimeler: Kavram, sanatçı kavramı, öğretmenlik kavramı, Tutum

\section{Attitudes of Visual Arts Teachers and Prospective Teachers towards the Concepts of 'Artist' and 'Teacher'}

\begin{abstract}
The purpose of this research is to analyze knowledge and attitudes of Visual Arts teachers and prospective teachers towards the concepts of 'Artist' and 'Teacher'. The research design employs a descriptive approach that is based on quantitative method. The research sample consists of 176 freshmen, junior and senior students studying in Department of Visual Arts and Fine Arts Education in Fatih Faculty of Education at Black Sea Technical University in Trabzon and 100 Visual Art Teachers, who work in schools administered by the Ministry of National Education in Trabzon provinces. For data collection purposes, a Personal Information Form and an Attitude Scale for Concepts of "Artist" and "Teacher" were used.
\end{abstract}

\footnotetext{
* Bu çalışma ikinci yazarın danışmanlığında birinci yazar tarafından hazırlanan yüksek lisans tezinden üretilmiştir.

** Trabzon Üniversitesi, Fatih Eğitim Fakültesi, Güzel Sanatlar Eğitimi Bölümü, Trabzon, Türkiye, e-mail: zumrutsen@trabzon.edu.tr, ORCID: 0000-0002-9116-3993

**** Trabzon Üniversitesi, Fatih Eğitim Fakültesi, Güzel Sanatlar Eğitimi Bölümü, Trabzon, Türkiye, e-mail: rkalyoncu@trabzon.edu.tr, ORCID: 0000-0002-8823-0315 (D)
}

Kaynak Gösterme: Şen, Z. \& Kalyoncu, R. (2020). Görsel sanatlar öğretmen adaylarının ve öğretmenlerinin sanatçı ve öğretmen kavramlarına yönelik tutumları. Bayburt Eğitim Fakültesi Dergisi, 15(29), 64-80. https://doi.org/10.35675/befdergi.652210 
Descriptive techniques and independent $t$ test were used for data analysis; Kruskall-Wallis techniques were used for non-parametric data. This situation has been suggestions, and some critical points have been made with respect to current and future research.

Keywords: Concept, artist concept, teacher concept, attitude

\section{Giriş}

Yaşadığımız dönemde ekonomik, sosyal ve teknolojik açıdan sürekli değişim ve gelişim yaşanmaktadır. Hızlı gelişmeler ile yaratıcı düşünen, araştıran, sorgulayan bireylerin yetiştirilmesinde sanat eğitiminin yeri ve etkisi büyüktür. Bu değişim ve gelişim ile birlikte sanat, sanat eğitimi, sanat eğitimcisi gibi kavramlarda değişiklikler göstermektedir. Sanatçının, sanat eğitimcisinin, öğretmenin nasıl olması, nitelikli bir sanat eğitimi için sanat eğitimi verilen kurumlarda ne gibi düzenlemelerin yapılması gerektiği tartışılmaktadır. "Toplumun, ülkenin geleceği için öğretmen ve öğretmenlik mesleği üzerinde gereğince ve yeterince durmalıyız. Bir eğitim sisteminin en önemli ögesi öğretmendir. İyi eğitimi iyi öğretmenler, nitelikli öğretimi de nitelikli öğretmenler yapar” (Kavcar, 2002, s.11). Nitelikli bir eğitimin sağlanabilmesi içinde şartların düzenlenmesi, koşulların iyileştirilmesi yoluna gidilmelidir. Gereken şartlar sağlandığında, alınan sanat eğitimi ile birlikte bireylerin ihtiyaçlarına cevap veren, yeteneklerine uygun, mesleki becerilerini geliştirebilecekleri alt yapı sağlanmış olacaktır.

Güzel sanatların hayatımıza girmesi ile kitleler tarafindan paylaşılır hale gelen sanat, sanatı benimseyenleri de olumlu etkilemektedir. $\mathrm{Bu}$ etkiler ile birlikte öğrencilerde değişmekte, kendilerine ve çevrelerine saygı duyan, analiz sentez yapabilen, yaratıcı niteliklerini kullanabilen, yeniliklere açık bireyler haline gelmektedirler. "Sanat eğitimi kendini yenileyebilmeli, değişen öğrenci modelinin ihtiyaçlarına göre çağdaşlaşabilmelidir. Sadece sanat eğitimi ile değil tüm eğitim programları temel değerlerinin yanında, çağın değişen ve gelişen şartlarına göre kendini yenileyebilmelidir" (Buyurgan, 2007, s.144).

Yeni yaklaşımların uygulandığı müfredat programı öğrenciyi merkeze alan, araştırmaya yönlendiren, öğretmen rehberliğinde, aşamalı bir biçimde birikim ve deneyimlerle sorunlara çözüm üretebilme amacını gütmektedir. Bu uygulamaları yapabilecek Görsel Sanatlar Eğitimi programına uygun yeterlilik sahibi öğretmenlerin yetiştirilmesi gerekmektedir. Sanat nedir? Sanatçı kimdir, nasıl olmalıdır? Sanat eğitimcisi kimdir, nasıl olmalıdır? Üniversitelerde öğretmen adaylarına verilen eğitim öğretmenlik yapabilmeleri için yeterli midir? Sanat Eğitimi ve Görsel Sanatlar Eğitimi alan sanatçı ve öğretmen adaylarının bu sorulara cevap verilebilmesi, bilgi sahibi olması, bilgi sahibi değilseler bu bilgilerin adaylara kazandırılması gerekmektedir.

Sanat eğitiminin, diğer disiplinlerden farklı bir yaratma süreci vardır. Gelişen dünyada toplumların ihtiyaç duyduğu bireylerin yetiştirilebilmesi, öğrencilerin kendi öğrenmelerini kurgulayıp yönlendirdikleri, kendi başarıları konusunda karar verici 
oldukları, karşılaştıkları problemleri iş birliği içerisinde çözmeye çalıştıkları, bir öğrenme ortamıdır (Kalyoncu, 2009). Nitelikli bir sanat eğitimi için sadece bilgi ve becerilerin öğrencilere kazandırılması yeterli değildir, önemli olan bireyin farklı fikirleri sentezleyip ortaya ürünler çıkararak yeteneğini geliştirmesi, kazandığı bu davranışları gerektiği zaman ve gerektiği yerde uygulayabilmesidir.

Türkiye genelindeki fakültelerin Güzel Sanatlar Bölümlerindeki adlandırılmaya bakıldığında Resim İş Öğretmenliği adı altında öğretmen adayları yetiştirilmeye devam edilmektedir. Sanat eğitimi daha genel bir kapsamken Resim İş Öğretmenliği de aynı kapsamda düşünülerek adlandırılmaktadır. Günümüzde kullanılan çoğu müfredatta Resim İş̧ Öğretmenliği yerine Görsel Sanatlar Öğretmenliği ismi kullanılmaktadır. Resim İş Öğretmenliği bölümünden mezun olan öğretmen adayları atanma hakkı kazanınca Görsel Sanatlar Öğretmeni olarak atanmakta ve göreve başlamaktadır. Resim İş Öğretmenliği adlandırması kısıtlı kalırken, Görsel Sanatlar Öğretmenliği ismi alanın içeriğini karşılamakta mıdır?

Ayaydın'a (2009) göre; İlköğretimde yer alan Resim-İş dersleri yeniden yapılanma süreci içinde "Görsel Sanatlar" olarak adlandırılmıştır. Bu süreç içinde Görsel Sanatlar dersi olarak yeni ve daha çağdaş bir içeriğe de kavuşturulmuştur. Ancak ilköğretimde bu dersi yürütecek öğretmenleri mezun eden birimin adı hala Resim-İş Öğretmenliği olarak devam etmektedir. Yani bu birimdeki öğretmen adayları Resim-İş Öğretmenliği adı altında okumakta, Resim-İş Öğretmeni adayı olarak, aslında olmayan bir öğretmenliğe hazırlanmakta ve mezun olunca ise Görsel Sanatlar Öğretmeni olarak atanmaktadır.

Araştırma sürecinde Resim İş Öğretmenliği Bölümlerindeki en önemli tartışma konularından biri olan adlandırma sorunu dikkat çekmiştir. Resimden ziyade plastik sanatlar, tasarım teknikleri, 2 ve 3 boyutlu çalışmalar, baskı vb. gibi diğer teknikleri de öğretecek olan öğretmenleri yetiştiren Resim İş Öğretmenliği Bölümlerinin adlarının değiş̧tirilmesinin anlam karışıklığının giderilmesine yardımcı olacağı düşünülmektedir.

Ülkemizde Görsel Sanatlar Eğitimi ile ilgili sorunlar okul öncesi dönemden başlayıp eğitim sürecinin geneline yayılır. Eğer sanat eğitimi zamanında ve düzgün şekilde verilemezse bu aksaklıklar eğitimin diğer dönemlerine de yayılmaya devam edecektir. "Görsel Sanatlar Öğretmenleri hayati öneme sahiptirler ve öğrenme sürecinde oynayacakları çok önemli rolleri vardır. Bu nedenle öğrenme sürecine ilişkin temel bilgilerle donanmış olmalıdırlar" (Özsoy, 2007, s.136). Eğitimin en temel unsuru olan öğretmenlerin yetiştirilmesi konusundaki eksiklikler ve bilgisizlikler öğretmenin niteliklerini geliştirmekte yetersiz kalmaktadır. Etkili öğretmen, öğrencilerin eğitim öğretim etkinliklerine ilişkin tutum ve düşüncelerini denemelerine olanak sağlar, onları güdüleyerek verimliliklerini ve performanslarını arttırabilecek düşünce ve davranışlar kazanmaları yönünde yardımcı olur (Can, 2004). 
Öğretmen ve sanatçı adayları aldıkları sanat eğitimi sonrasında seçecekleri mesleğe yönelik olumlu tutum sergilemelidirler. Resim iş öğretmeni yetiştirirken, sanat eğitiminin önemi, işlevleri, sanatsal yaratma süreci, çalışma alanları, öğrenim durumları öğretmen yetiştirme programına tam olarak yansıyabilmelidir (Kırışoğlu, 2005).

Sanat eğitimi ile kazandırılması gereken davranış ve tutumlarda eksiklikler kendini göstermektedir. Herbert Read, bir yapıtında sanat ve eğitimin gerekliliğini "Sanat hayata uygulanan öyle bir mekanizmadır ki onsuz toplumlar dengelerini kaybederler" deyişiyle vurgularken (Artut, 2009, s.120) Buyurgan, sanat eğitimi temelde sanatsal etkinlikler yoluyla bireylerin ve toplumun içinde yaşadıkları çevreye duyarlı olmalarını sağlamaya, çevreleri ile yararlı bir etkileşim içine girebilmelerine, estetik ihtiyaçlarını karşılamaya, ürün ortaya koyabilme ve yorumlama güdülerini doyurmaya, yaşantılarını daha anlamlı hale getirebilmelerine imkân vermeye yönelik düşüncededir, diyerek sanat eğitiminin önemini ifade etmiştir (Buyurgan, 2007). Yani buradan anlaşılacağı gibi sanat eğitimi ile öğrenci önce kendini tanır, içinde yaşadığı toplum ile iletişim kurar daha sonrada yaşadığ 1 toplumda meydana gelen problemleri gören ve bu problemlere çözüm yolları üretebilen bireyler olurlar (Türe, 2007, s.39).

Amacımız; üniversitelerin eğitim fakültelerinde Görsel Sanatlar Eğitimi bölümlerinde sanat eğitimi alan sanatçı ve öğretmen adaylarının aldıkları sanat eğitimi ile birlikte görev yapan Görsel Sanatlar Öğretmenlerinin sanatçı ve öğretmen kavramlarına karşı nasıl tutumlar sergiledikleri incelemektir. Bu kavramlar öğretmen adaylarına ve Milli Eğitim Bakanlığında görev yapan Görsel Sanatlar Öğretmenlerine sorulduğunda sanatçı ve öğretmen kavramlarına yönelik ne kadar bilgi sahibi olduklarını belirlemek ve kavramlara yönelik tutumlarının ne düzeyde olduğunu tespit etmektir. Sanatçı ve öğretmen adaylarının seçtikleri mesleğe yönelmelerini sağlayan etkenlerin sanatçı ve öğretmen kavramlarına yönelik tutumlarına etki edip etmediğini ortaya çıkarmaktır.

Uygulayacağımız kişisel bilgi formu, sanatçı ve öğretmen kavramlarına yönelik tutum ölçeği ile birlikte Resim İş Öğretmenliği Bölümünde okuyan öğretmen adayları ve Milli Eğitim Bakanlığında görev yapan Görsel Sanatlar Öğretmenlerinin sanatçı ve öğretmen kavramlarına yönelik tutumları arasında cinsiyet, sınıf düzeyi, öğrenim görülen okula ve diğer etkenlere göre anlamlı farklılıkların olup olmadığı saptanmaya çalışılacaktır. Alt problem cümlelerinin çözümleri bulunmaya çalışılacak, bu sayede de alt problemlerin çözümü ile ana problemin çözümüne ulaşılacaktır.

\section{Araştırmanın Amacı}

$\mathrm{Bu}$ araştırmanın amacı Görsel Sanatlar öğretmen adaylarının ve öğretmenlerinin sanatçı ve öğretmen kavramlarıyla ilgili bilgi ve tutumlarını incelemektir. 


\section{Alt amaçlar}

1. Resim İş Öğretmenliği Bölümünde okuyan öğrencilerin "sanatçı" kavramına ilişkin tutumları arasında anlamlı bir fark var mıdır?

2. Resim İș Öğretmenliği Bölümünde okuyan öğrencilerin “öğretmen” kavramına ilişkin tutumları arasında anlamlı bir fark var mıdır?

3. Resim İş Öğretmenliği Bölümünde okuyan öğrencilerin "sanatçı" kavramına ilişkin tutumları arasında cinsiyete dayalı fark var mıdır?

4. Resim İş̧ Öğretmenliği Bölümünde okuyan öğrencilerin “öğretmen” kavramına ilişkin tutumları arasında cinsiyete dayalı fark var mıdır?

5. Resim İş Öğretmenliği Bölümünde okuyan öğrencilerin "sanatçı" kavramına ilişkin tutumları arasında sınıf düzeyine dayalı fark var mıdır?

6. Resim İş̧ Öğretmenliği Bölümünde okuyan öğrencilerin “öğretmen” kavramına ilişkin tutumları arasında sınıf düzeyine dayalı fark var mıdır?

7. Resim İş Öğretmenliği Bölümünde okuyan öğrencilerin "sanatçı" kavramına ilişkin tutumları arasında mezun oldukları liseye dayalı (GSL ve diğerleri) fark var midir?

8. Resim İş Öğretmenliği Bölümünde okuyan öğrencilerin "öğretmen” kavramına ilişkin tutumları arasında mezun oldukları liseye dayalı (GSL ve diğerleri) fark var midir?

9. Görsel sanatlar öğretmenlerinin "sanatçı" kavramına ilişkin tutumları arasında cinsiyete dayalı fark var midır?

10. Görsel sanatlar öğretmenlerinin "öğretmen” kavramına ilişkin tutumları arasında cinsiyete dayalı fark var midır?

\section{Yöntem}

Araştırmada nicel araştırma yaklaşımı kullanılmıştır. Bu kapsamda nicel verilerin elde edilebilmesi için alan taraması yöntemi (Survey) kullanılmıştır. Araştırma Resim İş Öğretmenliği Bölümünde okuyan öğrencilerin ve Milli Eğitim Bakanlı̆̆ında görev yapan görsel sanatlar öğretmenlerinin sanatçı ve öğretmenlik kavramlarına yönelik tutumlarını betimlemeye yönelik olduğu için alan taraması yöntemi kullanılmıştır. "Alan taraması yöntemi çalışmaları mevcut durumu tespit etmek için yürütülen bir araştırma türüdür. Daha çok araştırılması istenen olayın veya problemin mevcut durumu nedir ve neredeyiz sorularına cevap aranır" (Çepni, 2010, s.65). Alan Taraması Yöntemi ile yürütülen çalışmalarda örneklemin kapsamı geniş tutulur, kapsamı geniş tutulan bir örnekleme ölçekler ile ulaşabilir. Ölçeklerden elde edilen nicel veriler sonucunda da genellemelere ulaşılmaya çalışılır.

Betimsel araştırmalarda genelde olayın ne olduğuna odaklanıldığını söyleyebiliriz. Betimleme neyin ne olduğunu, olayların nasıl başlayıp sürdüğü, olayın ya da kişinin neye benzediği ortaya konar (Punch, 2005, s.16). Bu model çerçevesinde, Resim İş Öğretmenliği Bölümünde okuyan öğrencilerin ve Milli Eğitim 
Bakanlığında görev yapan Görsel Sanatlar Öğretmenlerinin sanatçı ve öğretmenlik kavramlarına yönelik tutumlarının ne olduğu, veri toplama araçları ile edinilen bilgilere dayalı olarak betimlenmeye çalışılacaktır.

\section{Çalışma Grubu}

Araştırmanın çalışma grubunu Trabzon ilinde bulunan Karadeniz Teknik Üniversitesi Fatih Eğitim Fakültesi Görsel Sanatlar Eğitimi Bölümü Resim İş Öğretmenliği Ana Bilim Dalında örgün ve ikinci öğretimde 1.,2.,3. ve 4. sınıflarda öğrenim gören 176 öğrenci ve Trabzon ili il merkezinde ve ilçe merkezlerinde Milli Eğitime bağlı okullarda görev yapan 100 Görsel Sanatlar Öğretmeni oluşturmaktadır. Araştırmaya gönüllü olarak katılmayı kabul eden öğrenciler ve öğretmenler çalışma grubuna dâhil edilmiştir. Araştırmanın katılımcıları $(\mathrm{K}=121, \mathrm{E}=55$ olmak üzere toplam 176 öğrenci, $\mathrm{K}=49$, $\mathrm{E}=51 \mathrm{olmak}$ üzere toplam $100 \mathrm{GSÖ)}$ ' den oluşmaktadır. Katılımcıların tamamının \%61,6'sı kadın, \%38,4'ü erkektir.

\section{Veri Toplama Araçları}

Araştırmada verileri toplamak ve araştırmanın problemlerine cevap aramak amacı ile nicel veri toplama araçlarına ihtiyaç duyulmuş ve kullanacağımız veri toplama araçları araştırmacı tarafından geliştirilmiştir.

$\mathrm{Bu}$ araştırmada veri toplamak amacıyla;

1. Resim İş Öğretmenliğinde öğrenim gören öğrenciler için 10 maddelik, Görsel Sanatlar Öğretmenleri için 9 maddelik ayrı hazırlanmış 'Kişisel Bilgi Formu',

2. Resim İş Öğretmenliğinde öğrenim gören öğrencilerle Görsel Sanatlar Öğretmenlerinin 'Sanatçı' ve 'Öğretmenlik' kavramlarıyla ilgili tutumlarını belirlemek amacıyla hazırlanan 49 maddelik tutum ölçeği olmak üzere toplam 2 farklı veri toplama aracı geliştirilmiştir.

Tutum ölçeği maddeleri hazırlanırken farklı kaynaklardan literatür taraması yapılarak araştırmacı tarafından sanatçı ve öğretmenlik kavramlarıyla ilgili olumlu ya da olumsuz iki yüzün üzerinde soru maddesi hazırlanmış, daha sonra sorular üzerinde eleme yapılarak ölçek soruları sanatçılık kavramına yönelik 50, öğretmenlik kavramına yönelik 50 soruya düşürülmüştür. Bu süreçte iki farklı gruptan öğretmen adayları ve öğretmenlerle zaman zaman bir araya gelinerek fikir ve görüşlerinden faydalanılmıştır. Uygulama hem Resim İş Öğretmenliği Ana Bilim Dalında öğrenim gören öğrenciler hem de Görsel Sanatlar Öğretmenleri ile yapılacağı için her iki gruba birden uygun düşecek olan ölçek soruları yüz soru içinden seçilerek soru sayısı sanatçılık kavramına yönelik 25, öğretmenlik kavramına yönelik 25 madde olarak toplam 50 soruya düşürülmüştür.

Hazırlanan tutum ölçeğinin geçerlik ve güvenirliğinin sağlanması için asıl uygulama öncesinde 100' er adet anket Ankara Gazi Üniversitesi ve Erzurum Atatürk Üniversitesine gönderilmiştir. $\mathrm{Bu}$ üniversitelerdeki resim iş öğretmen adayları 
tarafından doldurulmuş ve asıl uygulamadan önce geçerlilik ve güvenilirlik çalışması açısından 180 öğrenci üzerinde uygulanmıştır. Uygun bulunan 146 adet anket üzerinden veri analizi yapılmış yapılan analiz sonuncunda anketteki hatalı madde olarak görülen 24. madde çıkarılarak anket yeniden düzenlenmiştir. Başlangıçta 50 maddeden oluşan ölçme aracı (tutum ölçeği); uzman görüşleri, madde ayırt ediciliği, toplam madde korelasyonları, madde güçlük düzeyleri dikkate alınarak 49 maddeye düşürülmüştür.

\section{Verilerin Analizi}

Veri analizleri için SPSS 17.0 programı kullanılmıştır. Analiz kapsamında tanımlayıcı teknikler ile bağımsız t testi ve parametrik olmayan veriler için Kruskall-Wallis teknikleri kullanılmıştır.

\section{Bulgular ve Yorum}

\section{Birinci Alt probleme İlișkin Bulgular ve Yorumlar}

Resim İş Öğretmenliği Bölümünde okuyan öğrencilerin “sanatçı” kavramına ilişkin tutumları arasında anlamlı bir fark var midır?

Yapılan bağımsız t testinde Resim İş Öğretmenliği Bölümünde öğrenim gören öğrenciler ile Görsel Sanatlar dersi öğretmenlerinin sanatçı kavramına ilişkin tutumları arasında anlamlı fark gözlenmemiştir $(t=-0.36, \mathrm{p}>0.05)$.

Tablo 1.

Resim İş Ögretmenliği Bölümünde Öğrenim Göre Öğrenciler ile Görsel Sanatlar Dersi Öğretmenlerinin Sanatçı Kavramına İlişkin Tutumları

\begin{tabular}{lllllll}
\hline Değişken & $\mathrm{N}$ & Ort & $\mathrm{Ss}$ & $\mathrm{t}$ & $\mathrm{sd}$ & $\mathrm{p}$ \\
\hline Öğrenci & 176 & 4.11 & 0.43 & -0.36 & 274 & 0.72 \\
\hline Öğretmen & 100 & 4.13 & 0.39 & & & \\
\hline
\end{tabular}

\section{İkinci Alt Probleme İlişkin Bulgular ve Yorumlar}

Resim İş Öğretmenliği Bölümünde okuyan öğrencilerin “öğretmen” kavramına ilişkin tutumları arasında anlamlı bir fark var mıdır?

Resim İş Öğretmenliği Bölümünde öğrenim gören öğrenciler ile Görsel Sanatlar dersi öğretmenlerinin öğretmen kavramına ilişkin tutumları arasında anlamlı fark gözlenmemiştir $(t=-1.54, \mathrm{p}>0.05)$. 
Tablo 2.

Resim Işs Öğretmenliği Bölümünde Öğrenim Gören Öğrenciler ile Görsel Sanatlar Dersi Ögretmenlerinin Öğretmen Kavramına İlişkin Tutumları

\begin{tabular}{lllllll}
\hline Değişken & $\mathrm{N}$ & Ort & $\mathrm{Ss}$ & $\mathrm{t}$ & $\mathrm{sd}$ & $\mathrm{p}$ \\
\hline Öğrenci & 176 & 3.76 & 0.49 & 1.54 & 274 & 0.13 \\
\hline Öğretmen & 100 & 3.67 & 0.34 & & & \\
\hline
\end{tabular}

\section{Üçüncü Alt Probleme İlişkin Bulgular ve Yorumlar}

Resim İş Öğretmenliği Bölümünde okuyan öğrencilerin “sanatçı” kavramına ilişkin tutumları arasinda cinsiyete dayalı fark var midır?

Resim İş Öğretmenliği Bölümünde öğrenim gören kız ve erkek öğrencilerin sanatçı kavramına ilişkin tutumları arasında anlamlı fark gözlenmiştir $(t=-2.09$, $\mathrm{p}<0.05)$. Bu fark kız öğrencilerin puanlarının (Ort=4.16, $\mathrm{Ss}=0.37)$, erkek öğrencilerin puanlarından $(\mathrm{Ort}=4.01, \mathrm{Ss}=0.53)$ yüksek olmasından kaynaklanmaktadır.

Tablo 3.

Resim Iş̧ Ögretmenliği Bölümünde Öğrenim Gören Öğrencilerin

Sanatçı Kavramına İlişskin Tutumları Arasında Cinsiyete Dayalı Farkllılklar

\begin{tabular}{lllllll}
\hline Değişken & $\mathrm{N}$ & Ort & $\mathrm{Ss}$ & $\mathrm{t}$ & $\mathrm{sd}$ & $\mathrm{p}$ \\
\hline Kız & 121 & 4.16 & 0.37 & 2.09 & 174 & 0.05 \\
\hline Erkek & 55 & 4.01 & 0.53 & & &
\end{tabular}

\section{Dördüncü Alt Probleme İliş̧kin Bulgular ve Yorumlar}

Resim İş Öğretmenliği Bölümünde okuyan öğrencilerin “öğretmen” kavramına ilişkin tutumları arasında cinsiyete dayalı fark var midır?

Resim İş Öğretmenliği Bölümünde öğrenim gören k1z ve erkek öğrencilerin öğretmen kavramına ilişkin tutumları arasında anlamlı fark gözlenmemiştir $(t=-1.23$, $\mathrm{p}>0.05)$.

Tablo 4.

Resim İs Öğretmenliği Bölümünde Öğrenim Gören Öğrencilerin Öğretmenlik

Kavramına İlişkin Tutumları Arasında Cinsiyete Dayalı Farklılıklar

\begin{tabular}{lllllll}
\hline Değişken & $\mathrm{N}$ & Ort & $\mathrm{Ss}$ & $\mathrm{t}$ & $\mathrm{sd}$ & $\mathrm{p}$ \\
\hline Kız & 121 & 3.79 & 0.51 & 1.23 & 174 & 0.22 \\
\hline Erkek & 55 & 3.70 & 0.42 & & & \\
\hline
\end{tabular}

\section{Beşinci Alt Probleme İlişkin Bulgular ve Yorumlar}

Resim İş Öğretmenliği Bölümünde okuyan öğrencilerin "sanatçı" kavramına ilişkin tutumları arasında sinıf düzeyine dayalı fark var mıdır?

Öğrencilerin sanatçı kavramına ilişkin tutumlarının sınıf düzeyine bağlı olarak farklılaşıp farklılaşamadığını test etmek için Kruskal Wallis testi kullanılmıştır. Elde 
edilen sonuçlara göre öğrencilerin sanatçı kavramına ilişkin tutumları sınıf düzeyine bağlı olarak anlamlı fark göstermemiştir $(\chi 2=3.11, \mathrm{sd}=3, \mathrm{p}>0.05)$.

Tablo 5 .

Resim İş Öğretmenliği Bölümünde Öğrenim Gören Öğrencilerin Sanatçı Kavramına İlişkin Tutumları Arasında Sinıf Düzeyine Dayalı Farklılıklar

\begin{tabular}{|c|c|c|c|c|c|c|}
\hline Sinif & & $\mathrm{N}$ & $\begin{array}{c}\text { Ortalama } \\
\text { Sira Farkı }\end{array}$ & $\chi^{2}$ & $\mathrm{sd}$ & $\mathrm{p}$ \\
\hline \multirow[t]{5}{*}{ Sanatçı } & 1.Sinif & 25 & 89,48 & 3,11 & 3 & 0,38 \\
\hline & 2.Sinif & 27 & 103,89 & & & \\
\hline & 3.Sinıf & 59 & 85,75 & & & \\
\hline & 4.Sinıf & 65 & 84,23 & & & \\
\hline & Toplam & 176 & & & & \\
\hline
\end{tabular}

\section{Altıncı Alt Probleme İlişkin Bulgular ve Yorumlar}

Resim İş Öğretmenliği Bölümünde okuyan öğrencilerin “öğretmen” kavramına ilişkin tutumları arasında sınıf düzeyine dayalı fark var mıdır?

Öğrencilerin öğretmen kavramına ilişkin tutumlarının sınıf düzeyine bağlı olarak farklılaşıp farklılaşamadığını test etmek için Kruskal Wallis testi kullanılmıştır. Elde edilen sonuçlara göre öğrencilerin öğretmen kavramına ilişkin tutumları sınıf düzeyine bağlı olarak anlamlı fark göstermemiştir $(\chi 2=4.01, \mathrm{sd}=3, \mathrm{p}>0.05)$.

Tablo 6.

Resim İş Öğretmenliği Bölümünde Öğrenim Gören Ögrencilerin Öğretmenlik Kavramına Iliş̧kin Tutumları Arasında Sınıf Düzeyine Dayalı Farklılıklar

\begin{tabular}{llccccc}
\hline \multirow{2}{*}{ Sınıf } & & $\mathrm{N}$ & Ortalama & & & \\
Sanatçı & Sira Fark1 & $\chi^{2}$ & sd & $\mathrm{p}$ \\
& 2.Sınıf & 25 & 81,84 & 4.01 & 3 & 0.26 \\
& 3.Sinıf & 27 & 102,65 & & & \\
& 4.Sınıf & 59 & 92,33 & & & \\
& Toplam & 65 & 81,71 & & & \\
\hline
\end{tabular}

\section{Yedinci Alt Probleme İlişkin Bulgular ve Yorumlar}

Resim İş Öğretmenliği Bölümünde okuyan öğrencilerin "sanatçı” kavramına ilişkin tutumları arasında mezun oldukları liseye dayalı (GSL ve diğerleri) fark var mıdır?

Resim İş Öğretmenliği Bölümünde öğrenim gören öğrencilerin GSL ile diğer mezun olunan liselere göre sanatçı kavramına ilişkin tutumları arasında anlamlı fark gözlenmemiştir ( $t=1.09, \mathrm{p}>0.05)$. 
Tablo 7.

Güzel Sanatlar Liselerinde ve Diğer Liselerde Öğrenim Gören Öğrencilerin Sanatçı Kavramına İlişkin Tutumları Arasında Farklılıklar

\begin{tabular}{lllllll}
\hline Değişken & $\mathrm{N}$ & Ort & $\mathrm{Ss}$ & $\mathrm{t}$ & $\mathrm{sd}$ & $\mathrm{p}$ \\
\hline Güzel SL & 56 & 4.16 & 0.42 & 1.09 & 174 & 0.27 \\
\hline Diğer Liseler & 120 & 4.09 & 0.44 & & & \\
\hline
\end{tabular}

\section{Sekizinci Alt Probleme İlişkin Bulgular ve Yorumlar}

Resim İş Öğretmenliği Bölümünde okuyan öğrencilerin “öğretmen” kavramına ilişkin tutumları arasında mezun oldukları liseye dayalı (GSL ve diğerleri) fark var mıdır?

Resim İş Öğretmenliği Bölümünde öğrenim gören öğrencilerin GSL ile diğer mezun olunan liselere göre öğretmen kavramına ilişkin tutumları arasında anlamlı fark gözlenmemiştir $(t=0,43, \mathrm{p}>0.05)$.

Tablo 8.

Güzel Sanatlar Liselerinde ve Diğer Liselerde Öğrenim Gören Öğrencilerin Öğretmen Kavramına İlişkin Tutumları Arasında Farklılıklar

\begin{tabular}{lllllll}
\hline Değişken & $\mathrm{N}$ & Ort & $\mathrm{Ss}$ & $\mathrm{t}$ & $\mathrm{sd}$ & $\mathrm{p}$ \\
\hline Güzel SL & 56 & 3.78 & 0.51 & 0,43 & 174 & 0.67 \\
\hline Diğer Liseler & 120 & 3.75 & 0.48 & & & \\
\hline
\end{tabular}

\section{Dokuzuncu Alt Probleme İlişkin Bulgular ve Yorumlar}

Görsel sanatlar öğretmenlerinin "sanatçı" kavramına ilişkin tutumları arasında cinsiyete dayalı fark var mıdır?

Görsel Sanatlar Öğretmenlerinin sanatçı kavramına ilişkin tutumları arasında cinsiyetlerine göre anlamlı fark gözlenmemiştir $(t=1.70, \mathrm{p}>0.05)$.

Tablo 9.

Görsel Sanatlar Öğretmenlerinin Sanatçı Kavramına İlişkin Tutumları Arasında Cinsiyete Dayalı Farklılıklar

\begin{tabular}{lllllll}
\hline Değişken & N & Ort & Ss & t & sd & p \\
\hline Kız & 42 & 4.20 & 0.37 & 1.70 & 97 & 0.09 \\
\hline Erkek & 57 & 4.07 & 0.53 & & & \\
\hline
\end{tabular}

\section{Onuncu Alt Probleme İlişkin Bulgular ve Yorumlar}

Görsel sanatlar öğretmenlerinin "öğretmen” kavramına ilişkin tutumları arasında cinsiyete dayalı fark var midır?

Görsel Sanatlar Öğretmenlerinin öğretmen kavramına ilişkin tutumları arasında cinsiyetlerine göre anlamlı fark gözlenmemiştir $(t=1.75, \mathrm{p}>0.05)$. 
Tablo 10.

Görsel Sanatlar Ögrretmenlerinin Öğretmenlik Kavramına İlişkin Tutumları Arasında Cinsiyete Dayalı Farkllilklar

\begin{tabular}{lllllll}
\hline Değişken & $\mathrm{N}$ & Ort & Ss & $\mathrm{t}$ & $\mathrm{sd}$ & $\mathrm{p}$ \\
\hline Kuz & 42 & 3.69 & 0.44 & 1.75 & 97 & 0.65 \\
\hline Erkek & 57 & 3.66 & 0.25 & & & \\
\hline
\end{tabular}

\section{Sonuç}

"Görsel Sanatlar Öğretmen Adaylarının ve Öğretmenlerinin Sanatçı ve Öğretmen Kavramlarına Yönelik Tutumları" adlı bu araştırmada aşağıdaki sonuçlara ulaşılmıştır.

Resim İş Öğretmenliği Bölümünde öğrenim gören öğrenciler ile Görsel Sanatlar dersi öğretmenlerinin sanatçı ve öğretmen kavramına ilişkin tutumları arasında anlamlı fark gözlenmediği sonucuna ulaşılmıştır. Bu sonuçlara göre, görev yapan Görsel Sanatlar Öğretmenleri ile öğrenim gören öğrencilerin sanatçı ve öğretmen kavramlarına bakışları arasında herhangi bir farklılık kendini göstermemektedir.

Resim İş Öğretmenliği Bölümünde öğrenim gören kı ve erkek öğrencilerin sanatçı kavramına ilişkin tutumları arasında cinsiyete göre anlamlı fark gözlendiği sonucuna ulaşılmıştır. Bu sonuca bakıldığında Resim İş Öğretmenliği bölümündeki kız ve erkek öğrencilerin sanatçı kavramlarına yönelik tutumlarını cinsiyet farklılıklarının etkilediği gözlemlenmektedir. Resim İş Öğretmenliği Bölümünde öğrenim gören kız ve erkek öğrencilerin öğretmenlik kavramına ilişkin tutumları arasında anlamlı fark gözlenmediği sonucuna ulaşılmıştır. Bu sonuca bakıldığında resim iş öğretmenliği bölümündeki öğrencilerin öğretmenlik kavramlarına yönelik tutumlarını cinsiyet farklılıkların etkilemediği gözlemlenmektedir.

Öğrencilerin sanatçı ve öğretmen kavramlarına ilişkin tutumlarının sınıf düzeyine bağlı olarak farklılaşıp farklılaşamadığını test etmek için Kruskal Wallis testi kullanılmıştır. Elde edilen sonuçlara göre öğrencilerin sanatçı ve öğretmen kavramlarına ilişkin tutumları sınıf düzeyine bağlı olarak anlamlı fark göstermediği sonucuna ulaşılmıştır.

Resim İş Öğretmenliği Bölümünde öğrenim gören öğrencilerin mezun oldukları liseye göre (GSL ve diğerleri) sanatçı ve öğretmen kavramlarına ilişkin tutumları arasında anlamlı fark gözlenmediği sonucuna ulaşılmıştır. Görsel Sanatlar Öğretmenlerinin sanatçı ve öğretmen kavramına ilişkin tutumları arasında cinsiyetlerine göre anlamlı fark gözlenmediği sonucuna ulaşılmıştır.

\section{Çıkar Çatışması ve Etik Bildirimi}

Yazarlar arasında çıkar çatı̧ması bulunmadı̆̆ını ve tüm araşıırmacıların çalışmaya katkı sunduğunu beyan etmiş̧tir. Yazarlar tüm etik kurallara uyduklarını bildirmiştir. 


\section{Kaynakça}

Artut, K. (2009). Sanat ěgitimi kuramları ve yöntemleri. Ankara: Anı Yayıncılık.

Ayaydın, A. (2009). Güzel sanatlar eğitimi resim-iş öğretmenliği anabilim dallarının sorunları ve çözüm önerileri. M. Ü. Atatürk Eğitim Fakültesi Eğitim Bilimleri Dergisi, 30, 31-45.

Buyurgan, S. (2007). Sanat eğitimi ve öğretimi, eğitimin her kademesine yönelik yöntem ve tekniklerle. Ankara: Pegem A Yayıncılık.

Can, N. (2004). Öğretmenlerin geliştirilmesi ve etkili öğretmen davranışları. Sosyal Bilimler Enstitüsü Dergisi, 16(1),103-119.

Çepni, S. (2010). Araştırma ve proje çalışmalarına giriş. Trabzon: Celepler Matbaacılık.

Kalyoncu, R. (2009). Illkögretim 8. sinıf görsel sanatlar dersi kent projesi konusunda proje tabanlı ögrenmeye dayalı bir uygulama örneği. (Doktora tezi). Ankara, Gazi Üniversitesi.

Kavcar, C. (2002). Cumhuriyet döneminde dal öğretmeni yetiştirme. Ankara Üniversitesi Eğitim Bilimleri Fakültesi Dergisi. 35(1-2), 1-14.

Kırışoğlu, O. T. (2005). Sanatta eğitim, görmek, öğrenmek, yaratmak. Ankara: Pegem A Yayınc1lı.

Özsoy, V. (2007). Görsel sanatlar eğitimi, resim iş eğitiminin tarihsel ve düşünsel temelleri. Ankara: Gündüz Eğitim ve Yayıncılık.

Punch, K. F. (2005). Sosyal araştırmalara giriş, nicel ve nitel yaklaşımlar. Ankara: Siyasal Kitabevi.

Türe, N. (2007). Eğitimde ve öğretimde bir araç olarak görsel sanatlar eğitiminin öğrencilere sağladı̆̆ katkılar (Yüksek lisans tezi). Konya, Selçuk Üniversitesi. 


\section{Ekler}

\section{Ek 1. Sanatçı ve Öğretmen Kavramlarına Yönelik Tutum Ölçeği}

\begin{tabular}{|c|c|c|c|c|c|}
\hline \multicolumn{6}{|c|}{ SANATÇI VE ÖĞRETMEN KAVRAMLARINA YÖNELIK TUTUM ÖLÇEĞİ } \\
\hline $\begin{array}{l}\text { Aşağıdaki her cümleyi okuduktan sonra okuduğunuz cümleye ne } \\
\text { derecede katıldı̆̆ınızı kesinlikle katılıyorum, oldukça } \\
\text { katılıyorum, kararsızım, çok az katılıyorum, kesinlikle }\end{array}$ & 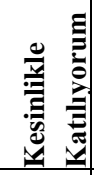 & 总 & 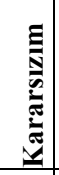 & 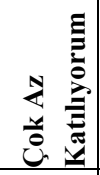 & : \\
\hline $\begin{array}{l}\text { katılmıyorum şeklinde, cümlenin yan tarafında bulunan } \\
\text { kutucuklardan bir tanesini }(\mathbf{x}) \text { şeklinde işaretleyerek belirtiniz. }\end{array}$ & 5 & 4 & 3 & 2 & 1 \\
\hline $\begin{array}{l}\text { 1. İyi bir Görsel Sanatlar Öğretmeni aynı zamanda iyi bir } \\
\text { sanatçıdır. }\end{array}$ & & & & & \\
\hline $\begin{array}{l}\text { 2. Görsel Sanatlar Öğretmenliği zevk alarak yapabileceğim bir } \\
\text { meslektir. }\end{array}$ & & & & & \\
\hline $\begin{array}{l}\text { 3. Eğitim hayatım boyunca aldığım sanat eğitiminin meslek } \\
\text { hayatımda yeterli olacağına inanıyorum. }\end{array}$ & & & & & \\
\hline $\begin{array}{l}\text { 4. Benim için en uygun mesleğin Görsel Sanatlar Öğretmenliği } \\
\text { olduğuna inanyorum. }\end{array}$ & & & & & \\
\hline $\begin{array}{l}\text { 5. Konulara uygun araç, gereç ve materyal hazırlamada } \\
\text { zorlanırım. }\end{array}$ & & & & & \\
\hline $\begin{array}{l}\text { 6. Mümkün olsaydı Görsel Sanatlar Öğretmenliği yerine başka } \\
\text { bir meslek seçerdim. }\end{array}$ & & & & & \\
\hline $\begin{array}{l}\text { 7. Resim İş Öğretmenliği Bölümünü iş garantisi olduğu için } \\
\text { seçtim. }\end{array}$ & & & & & \\
\hline $\begin{array}{l}\text { 8. Görsel Sanatlar Öğretmeninin sanatçı kişiliğe sahip olması } \\
\text { öğretmenliğini olumlu yönde etkiler. }\end{array}$ & & & & & \\
\hline $\begin{array}{l}\text { 9. Görsel Sanatlar Öğretmenliği özveri gerektiren, sorumluluk } \\
\text { isteyen zor bir meslektir. }\end{array}$ & & & & & \\
\hline $\begin{array}{l}\text { 10. İyi bir Görsel Sanatlar Öğretmeni öğrencilerinin karşılaştığı } \\
\text { sorunları çözebilmelidir. }\end{array}$ & & & & & \\
\hline $\begin{array}{l}\text { 11. Görsel Sanatlar Öğretmeninin deneyimleri verdiği eğitimi } \\
\text { olumlu yönde etkiler. }\end{array}$ & & & & & \\
\hline $\begin{array}{l}\text { 12. İyi bir Görsel Sanatlar Öğretmeni öğrencisinin ilgisini derse } \\
\text { çekebilmelidir. }\end{array}$ & & & & & \\
\hline $\begin{array}{l}\text { 13. İyi bir Görsel Sanatlar Öğretmeni öğrencilerine Görsel } \\
\text { Sanatlar dersinin önemini vurgulamalıdır. }\end{array}$ & & & & & \\
\hline $\begin{array}{l}\text { 14. Öğrencinin Görsel Sanatlar dersini sevmesini sağlamak } \\
\text { öğretmenin elindedir. }\end{array}$ & & & & & \\
\hline $\begin{array}{l}\text { 15. Resim İş Öğretmenliği Anabilim Dalında öğrenim gören bir } \\
\text { öğretmen adayı alanıyla ilgili kavramlarla ilgili olmalıdır. }\end{array}$ & & & & & \\
\hline $\begin{array}{l}\text { 16. İyi bir Görsel Sanatlar Öğretmeni öğrencilerin kendi } \\
\text { kişilikleri doğrultusunda gelişmelerine zemin hazırlamalıdır. }\end{array}$ & & & & & \\
\hline
\end{tabular}


17. İyi bir Görsel Sanatlar Öğretmeni olmak için yetenek tek başına yeterli değildir.

18. Özel sektörde çalışma imkânı bulursam Milli Eğitim Bakanlığı kadrolarında Görsel Sanatlar Öğretmenliği yapmayı düşünmem.

19. Kendimi alan bilgisi açısından yetersiz görüyorum.

20. Fakültede almış olduğum dersler öğretmenlik mesleği yapabilmem için yeterli değil.

21. Ders saati artırılırsa Görsel Sanatlar Öğretmenliğini daha büyük zevkle yaparım.

22. Sanatçı yaratııı ve üretken olmalıdır.

23. Görsel Sanatlar Öğretmenliği ile ilgili her şey ilgimi çeker.

24. Öğrencilerin yetiştirilmesi açısından Görsel Sanatlar Öğretmenliği diğer branşlardan daha önemlidir.

25. İyi bir sanatçı aynı zamanda iyi bir öğretmendir.

26. Sanatçının görevi yeteneklerini kullanarak sanatını izleyiciye sunmaktır.

27. Fakültede alınan dersler sanatçı olabilmek için yeterli değildir.

28. Bana göre sanatçı yaptığı eserlerle kendini ifade edebilendir.

29. Sanat eğitimi alan her birey iyi bir sanatçı olmayı ister.

30. Sanat eğitimi almak sanatı öğrenmektir.

31. Sanatçıların kendilerine ve toplumlarına faydaları büyüktür.

32. Kendimi pedagojik formasyon açısından yetersiz buluyorum.

33. Resim-İş Öğretmenliği Anabilim Dalı kişinin kendisini sanatsal yollarla ifade etmesine yardımcı olur.

34. Sanatçı eserlerinde heyecanını, mutluluğunu ve ruh halini izleyicilerine yansitmalıdır.

35. Sanatsal yaratıcılığın geliştirilmesi ve zenginleştirilmesi ile sanatçı olunur.

36. Resim-İş Öğretmenliği Bölümünde okumak bireylerin görsel algılarının gelişmesine yardımcı olur.

37. Sanatçının geliştirilebilir yaratıcı nitelikleri olmalı.

38. İyi bir sanatçı olabilmek için yetenekli ve istekli olmak gerekir.

39. Sanat eğitimi alan herkes sanatçı olamaz.

40.Sanatçı yeteneğini sanat dallarından birinde kullanarak ürün verir.

41. Her sanatçı belirli dönemlerde belli arayışlar içine girer.

42. Sanatçı yaşadığı zamanın duygularını, yaşam felsefesini ve eriștiği medeniyet seviyesini yansıtır.

43. Sanatçının tarzı yaşadığı çağa, çevresine göre değişir. 


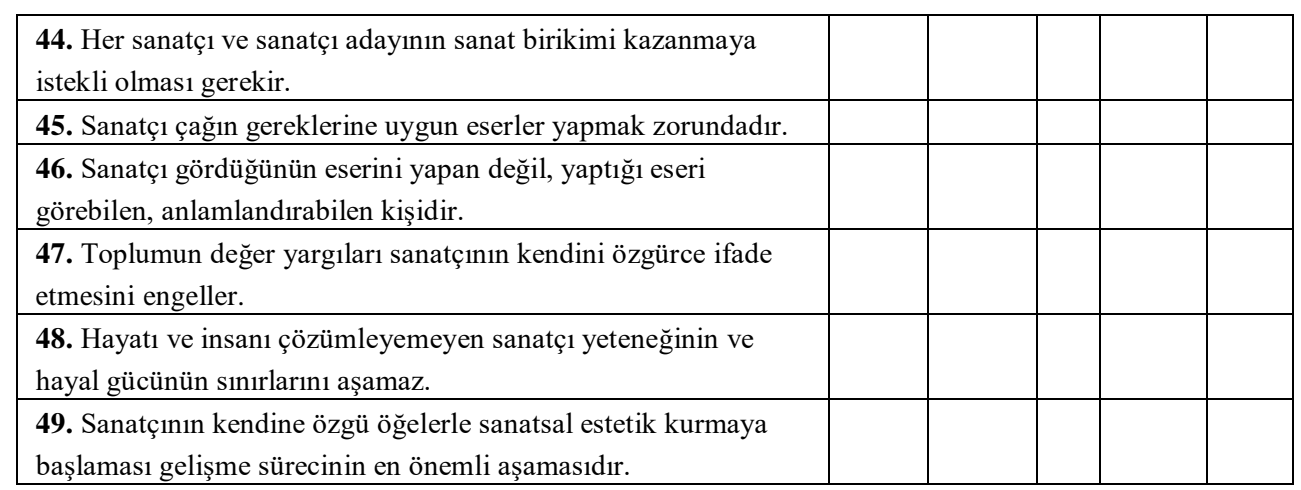

\section{Extended Abstract}

The purpose of this research is to analyze knowledge and attitudes of Visual Arts teachers and prospective teachers towards the concepts of 'Artist' and 'Teacher'. The research design employs a descriptive approach that is based on quantitative method. In this context, Field Survey Method (Survey) was used to obtain quantitative data. Since the research was aimed to describe the attitudes of the students studying at the Department of Painting and Teaching and the Visual Arts Teachers working in the Ministry of National Education towards the concepts of artist and teaching, Field Survey Method (Survey) was used. The attitudes of the students studying at the Department of Painting Teaching and Visual Arts Teachers working in the Ministry of National Education towards the concepts of artist and teaching were tried to be described based on the information gathered by means of data collection tools.

Quantitative data collection tools were needed in order to collect data and seek answers to the problems in the research and the data collection tools used were developed by the researcher.

In order to collect data,

1. A 10-item Personal Information Form for Visual Arts Teacher candidates and 9-item items for Visual Arts Teachers,

2. In order to determine the attitudes of the students of Visual Arts and Visual Arts Teachers about the concepts of 'Artist' and 'Teaching', a total of 2 different data collection tools, consisting of a 49-item attitude scale, were developed.

In the preparation of the attitude scale for the concepts of 'Artist' and 'Teaching', the 'Scale of attitude towards Artist and Teaching' was developed and used by the researcher. This scale was applied by the researcher, at different days and hours, to the students of the Department of Visual Arts Education of the Fatih Faculty of 
Education at the Karadeniz Technical University and the Visual Arts Teachers working at the Ministry of National Education.

The attitude scale used in the study was developed to determine the attitudes of the students studying in the Department of Visual Arts Education and Visual Arts teachers working in the Ministry of Education towards the concepts of artists and teachers. Before the attitude scale items were prepared, the literature was searched from different sources and over two hundred positive or negative questions were prepared by the researcher. Then, the questions were reduced to 50 questions for the concept of artistry and 50 questions for the concept of teaching. In this process, the researcher came together with the prospective teachers and teachers from time to time and benefited from their ideas and opinions. Since the application will be carried out with both visual arts students and Visual Arts Teachers, the scale questions that will be appropriate for both groups were selected from among 100 questions and the number of questions was reduced to 25 , for both concepts of artistry and teaching.

In order to ensure the validity and reliability of the attitude scale, 100 questionnaires were sent to Ankara Gazi University and Erzurum Atatürk University before the application. The questionnaires were completed by prospective teachers of painting and applied to 180 students in terms of validity and reliability study before the actual application. Data analysis was performed on 146 questionnaires that were found to be appropriate and the 24th item was removed, the questionnaire was reorganized. Initially, the scale consists of 50 items (attitude scale); by considering expert opinions, item discrimination, total item correlations, and item difficulty levels were reduced to 49 items. After all these procedures, the actual application was carried out. In the measurement tool, there are 49 attitude expressions, 35 positive and 14 negative. The 5-point Likert-type attitude scale questions are can be answered through in five categories.

The research sample consists of 176 freshmen, sophomore, junior and senior students studying in Department of Visual Arts and Fine Arts Education (both formal and evening classes) in Fatih Faculty of Education at Black Sea Technical University in Trabzon and 100 Visual Art Teachers, who work in schools administered by the Ministry of National Education in Trabzon city center and its provinces. Students and teachers who voluntarily agreed to participate in the study were included in the study group. The participants of the research consisted of 176 students and 100 teachers. Further, in the research, $61.6 \%$ of all participants were female and $38.4 \%$ were male. SPSS 17.0 program was used for data analysis. Descriptive techniques and independent t-test were used for the analysis and Kruskal-Wallis techniques were used for nonparametric data analysis. For data collection purposes, a Personal Information Form and an Attitude Scale for Concepts of 'Artist' and 'Teacher' were used.

No significant differences in attitudes towards 'Artist' and 'Teacher' concepts have been found between students of Fine Art Education and Visual Arts teachers. Some significant differences are observed between male and female students' 
attitudes towards the 'Artist' concept; however, there is no significant difference between their attitudes towards the 'teacher' concept. The students' attitudes towards the concepts of 'Artist' and 'Teacher' do not vary depending on their seniority. There is no significant difference in attitudes towards 'Artist' and 'Teacher' concepts between students who had graduated from Fine Arts High Schools and those that had graduated from other high schools. Finally, Visual Arts teacher's attitudes towards artist and teacher concepts do not vary significantly depending on their gender.

While some of the results corroborate the findings found in the literature; some of the results do not. This situation has been suggestions, and some critical points have been made with respect to current and future research. 